\title{
SARS-COV2 POSITIVE IN BONE MARROW TRANSPLANTATION ASYMPTOMATIC PATIENTS: THE EXPERIENCE IN A SINGLE CENTER OF CEARA, BRAZIL
}

\author{
Karine Sampaio Nunes Barroso ${ }^{1}$, Larissa Maria Gurgel Passos Gomes ${ }^{1}$, Nicole Pereira Leal, Lívia \\ Andrade Gurgel, João Paulo Vasconcelos Leitão' ', Beatriz Stela Gomes de Souza Pitombeira, \\ Romélia Pinheiro Gonçalves Lemes, Fernando Barroso Duarte, MD PHD ${ }^{1}$ \\ 1 Walter Cantidio University Hospital, Federal University of Ceara, Hematology Division, Fortaleza, CE, Brazil. 2 Faculty of \\ Pharmacy, Federal University of Ceará.
}

Correspondence to: Karine Sampaio Nunes Barroso - karinesampaionb@hotmail.com

\begin{abstract}
The bone marrow transplantation (BMT) recipient are susceptible to virus respiratory disease and their complications. The emergence of pandemic COVID-19, adapted their routine. We are a public schoolhospitalbonemarrowtransplantationcenter,localizedinFortaleza/Ceará,NortheastofBrazil. Objective: In the article we are described the asymptomatic SARS-CoV2 PCR positive in recipient pre and post bone marrow transplantation.

Methods: In total of 13 recipients collected of SARS-CoV2 PCR. The donors and recipients with high risk disease and selected to bone marrow transplantation in april to july of 2020 are submitted a nasopharyngeal and throat swab to collected PCR multiplex SARS-CoV2. Results: In total of 13 recipients we have 5 patients asymptomatic with positive results of the SARS-CoV2, 3 allogeneic recipient and 2 autologous. The 2 in patients follow the program because we have the result after the end of condition, we use GCSF in both and none had febrile neutropenia.
\end{abstract}

Conclusion: The results show us the importance of PCR multiplex SARS-CoV2 before hospital admission to avoid bone marrow transplantation at the moment of viral load and to organized the prevention precautions. This cases are important because described patients with SARS-CoV 2 PCR positive in the early transplant with asymptomatic course.

Keyword: asymptomatic, SARS CoV2, bone marrow transplantation.

\section{INTRODUCTION}

The bone marrow transplantation (BMT) recipient are susceptible to virus respiratory disease and their complications1. Until the emergence of pandemic COVID-19, the bone marrow of transplant centers around the World, based on Guidelines of the international societies, adapted their routine. We are a bone marrow transplantation center in a public university hospital, localized in Fortaleza/ Ceara, Northeast of Brazil. This city had the first case of COVID-19 diagnosed in March, 15 and the peak of epidemic in May2. During pandemic, in our center, only transplant for high risk disease are performed (aplastic anaemia, leukemias and lymphoma diseases)3,4, family visits to the unit were prohibited, we moved away the symptomatic health professional, acquired and freeze stem cell product before conditioning, turn off the positive pressure in the unit and performe the screening with SARS-CoV 2 RT- PCR to donors and recipient before hospitalization until April. The health professional screening with SARS-CoV 2 PCR were - performed every two weeks. In this article we are describing the asymptomatic SARS CoV2 RT$\mathrm{PCR}$ positive in recipient pre and post bone marrow transplantation. 


\section{METHODS}

This is a prospective study with donors and recipients with high risk disease and selected to bone marrow transplantation in april to july the 2020 submitted a nasopharyngeal and throat swab to collected PCR multiplex SARS-CoV2. The analyses were realized in Central Laboratory of Ceara (LACEN). All of them were informed about the social isolation until 28 days of the test and asked about symptoms and contact of suspected cases of COVID-19. SARS-CoV 2 RT-PCR positive collected of asymptomatic recipient were selected. The analyzed variables were: age (years), sex, disease, type of transplantation, time of transplantation of SARS-CoV2 positive previous symptoms, date of previous symptoms, previous SARS-CoV2 RT-PCR negative, date of positive test, date of negative test after positive, inpatient at the moment of RT-PCR positive, without corticoid and $D+$ graft neutrophils. The symptoms analyzed were fever, myalgia, fatigue, headache, cough, rhinorrhea, dyspnea, hypoxemia, throat ache, anosmia5.

\section{RESULTS}

In total of 13 recipients collected of SARS-CoV2 RT$\mathrm{PCR}$, we have 5 patients asymptomatic with positive results. Three patients to allogeneic transplant and two autologous. Two of them are inpatient, both collected when we had a mild symptomatic positive PCR multiplex SARS-CoV2 patient in the unit, one in the second day of hospitalization and the other in the seventh day. Two of then collected previous the hospitalization. And the last one, after two days of hospital discharger after mobilization failure, she was contact inpatient of positive RT-PCR multiplex SARSCoV2. No one had progression to symptomatic disease two weeks after the positive results. The oldest patient has 68 years old. One patient has high blood pressure. The two inpatients follow the program because we have the result after the end of conditioning chemotherapy, we use GCSF in both and none had febrile neutropenia. The patients had good clinical course, without symptoms, bone marrow failure or Graft versus Host Disease. In the same time, there was another inpatient, he was asymptomatic too and had three negatives tests RT-PCR SARS-CoV2. The inflammatory exams (C reactive protein) are normal.

TABLE 1 - Characteristic patient asymptomatic positive RT-PCR multiplex SARS-CoV2

\begin{tabular}{c|c|c|c|c|c}
\hline $\begin{array}{c}\text { ANALYZED } \\
\text { VARIABLES }\end{array}$ & PATIENT 1 & PATIENT 2 & PATIENT 3 & PATIENT 4 & PATIENT 5 \\
\hline Age (years) & 31 & 24 & 39 & 54 & 68 \\
\hline Sex & Male & Female & Male & Female & Female \\
\hline Disease & $\begin{array}{c}\text { Acute } \\
\text { lymphoblastic } \\
\text { leukemia Ph+ }\end{array}$ & Aplastic anaemia & $\begin{array}{c}\text { Acute myeloid } \\
\text { Leukemia }\end{array}$ & $\begin{array}{c}\text { Acute } \\
\text { promyelocitic } \\
\text { leukemia }\end{array}$ & $\begin{array}{c}\text { B cell non } \\
\text { Hodgkin } \\
\text { Lymphoma }\end{array}$ \\
\hline $\begin{array}{c}\text { Type of } \\
\text { transplantation }\end{array}$ & $\begin{array}{c}\text { Match related } \\
\text { allogeneic }\end{array}$ & $\begin{array}{c}\text { Match related } \\
\text { allogeneic }\end{array}$ & $\begin{array}{c}\text { Match related } \\
\text { allogeneic }\end{array}$ & Autologous & Autologous \\
\hline $\begin{array}{c}\text { Time of } \\
\text { transplantation } \\
\text { of SARS-CoV2 } \\
\text { positive }\end{array}$ & $\begin{array}{c}\text { Before BMT } \\
\text { Previous } \\
\text { symptoms }\end{array}$ & Before BMT & $\begin{array}{c}\text { D-6 conditioning } \\
\text { Infusion Day }\end{array}$ & Mobilization \\
\hline $\begin{array}{c}\text { Date of previous } \\
\text { symptoms }\end{array}$ & $\begin{array}{c}\text { No previous } \\
\text { symptoms }\end{array}$ & May, 17 (mild) & $\begin{array}{c}\text { No previous } \\
\text { symptoms }\end{array}$ & $\begin{array}{c}\text { No previous } \\
\text { symptoms }\end{array}$ & $\begin{array}{c}\text { No previous } \\
\text { symptoms }\end{array}$ \\
\hline $\begin{array}{c}\text { Previous SARS- } \\
\text { CoV2 PCR } \\
\text { negative }\end{array}$ & Yes & Not collected & Yes & Yes & Yes \\
\hline $\begin{array}{c}\text { Date of positive } \\
\text { test }\end{array}$ & $06 / 16 / 2020$ & $06 / 30 / 2020$ & $06 / 12 / 2020$ & $06 / 12 / 2020$ & 06/16/2020 \\
\hline \begin{tabular}{c} 
Nons \\
\hline
\end{tabular} & & & No & \\
\hline
\end{tabular}




\begin{tabular}{c|c|c|c|c|c}
\hline $\begin{array}{c}\text { Date of negative } \\
\text { test after positive }\end{array}$ & $07 / 07 / 2020$ & $7 / 07 / 2020$ & $07 / 14 / 2020$ & Not collected & $07 / 08 / 2020$ \\
\hline $\begin{array}{c}\text { Inpatient at the } \\
\begin{array}{c}\text { moment of PCR } \\
\text { positive }\end{array}\end{array}$ & No & No & $\begin{array}{c}\text { Yes } \\
(1 \text { day })\end{array}$ & $\begin{array}{c}\text { Yes } \\
(7 \text { days })\end{array}$ & $\begin{array}{c}\text { No }(2 \text { days } \\
\text { after hospital } \\
\text { discharge })\end{array}$ \\
\hline $\begin{array}{c}\text { Without corticoid } \\
\text { D+ graft } \\
\text { neutrophils }\end{array}$ & Yes & Yes & Yes & Yes & Yes \\
\hline
\end{tabular}

\section{DISCUSSION}

The immunocompromised state, comorbidity and high risk of morbimortality infection related with bone marrow transplantation become the COVID-19 a disease with high impact in our routine. The endemic Coronavirus is the forth cause of respiratory viral infection (17\%), and 34 of $112(30 \%)$ progressed to lower respiratory tract. The graft-versus-host disease (GVHD), corticosteroids, hypoalbuminemia, and older age are associated with infectious disease progression[1,4].

The time to had symptoms, after the contamination, varies between 2-14 days, and we have mild symptoms to severe acute respiratory distress syndrome4,5. And the asymptomatic patients occur in immunocompromised patient too.

The results show us the importance of RT-PCR multiplex SARS-CoV2 before hospital admission to avoid bone marrow transplantation at the moment of viral load and to organized the prevention precautions.

The strategies of prevention were implemented in our unit: hand washing, avoid visits, sick employees stay home, SARS-CoV2 RT-PCR screening for asypmtomatic employees and patients before hospitalization and adequate individual protective equipment.

Unfortunately, the nosocomial transmission occurs, the precautions, with PCR screening, avoid the admission to hospital to three patients asymptomatic and control the outbreak in the unit.

After the lifting of restrictions, several cities documented small outbreak, the careful and vigilance are important in the context of BMT. Follow with transplants in that conditions were a challenge. In that time, we need to return the frequency of service before outbreak with the same precautions.

This cases are important because described patients with SARS-CoV2 RT-PCR positive in the early transplant with asymptomatic course.

\section{CONCLUSION}

The results show us the importance of PCR multiplex SARS-CoV2 before hospital admission to avoid bone marrow transplantation at the moment of viral load and to organized the prevention precautions. This cases are important because described patients with SARS-CoV 2 PCR positive in the early transplant with asymptomatic course.

\section{ACKNOWLEDGE}

Laboratory investigators: Liana Perdigão Mello, Fernanda Montenegro de Carvalho Araújo and Maria Elisabeth Lisboa de Melo from Central Laboratory of Ceara (LACEN).

\section{REFERENCES}

1. Eichenberg EM, Soave R, Zappetti D, Small CB, Shore T, Besien Kv, Douglas C, Westblade LF, Satlin MJ. Incidence, significance, and persistence of human coronavirus infection in hematopoietic stem cell transplant recipients. Bone Marrow Transplantation. 2019 v.54, n.7, p.1058-1066.

2. https://www.saude.ce.gov.br/wp-content/ uploads/sites/9/2018/06/boletim_n14_ COVID_16_mar_20.pdf

3. Coronavirus disease COVID-19: EBMT recommendations. Version 9-june 15, 2020.

4. Ardura M, Hartley D, Dandoy C, Lehmann L, Jaglowski S, Auletta J. Addressing the Impact of the Coronavirus Disease 2019 (COVID-19) Pandemic on Hematopoietic Cell Transplantation: Learning Networks as a Means for Sharing Best Practices. Biology and Blood Marrow transplantation. 2020.

5. Yixuan Wang, Yuyi Wang, Yan Chen, and Qingsong Qin. Unique epidemiological and clinical features of the emerging 2019 novel coronavirus pneumonia (COVID-19) implicate special control measures. Journal of Medical virology. 2020, 1 p. 9. 